\title{
Penerapan Multimedia Interaktif untuk Meningkatkan Motivasi dan Hasil Belajar IPA Materi Struktur Organ Tubuh Manusia dan Fungsinya
}

\author{
Dinar Arena Tiari ${ }^{7}$, Nunuk Suryani ${ }^{8}$, Suharno ${ }^{9}$ \\ teea.sugar@gmail.com
}

\begin{abstract}
The purpose of this study was to: (1) Improving student motivation through the application of interactive multimedia in science for fourth grade at Brubuh 2 Elementary School; (2) Improving student learning outcomes through the application of interactive multimedia in science for fourth grade at Brubuh 2 Elementary School. This type of research is a classroom action research (PTK), the research subjects were 21 students of fourth grade at Brubuh 2 Elementary School. The research was conducted in two cycles, each cycle consisting of planning, action, observation, and reflection. Data collection techniques using the test (to measure student learning outcomes), the questionnaire (to measure student motivation), observation, interviews, and documentation. The validity of the data using triangulation techniques and data sources triangulation method. While the criteria for the success of this research if at least $80 \%$ of students had reached KKM (minimum completeness criteria) $\geq$ 70 , and the percentage of learners' motivation towards science learning using interactive multimedia by $80 \%$. The results showed that an increase in student learning outcomes, including an increase in the average grade of $60.38 \%$ pre-cycle into $72.41 \%$ in the first cycle and $83.09 \%$ in the second cycle. The lowest value increased from pre cycles 50 to 60 in the first cycle and 65 in the second cycle. The highest value increase of pre cycles 76 to 90 in the first cycle and 100 in the second cycle. The number of students who reach KKM $\geq 70$ also increased from $38.1 \%$ pre-cycle to $66.7 \%$ in the first cycle and $90.47 \%$ in the second cycle. The percentage of student motivation toward science learning by using interactive multimedia application amounted to $67.43 \%$ in the first cycle and increased to $84.23 \%$ in the second cycle. The second variable of this class action research has qualified research success criteria, that is motivation and completeness learning outcomes of students reached $80 \%$.
\end{abstract}

Keywords : Classroom Action Research, Interactive Multimedia, Science, Motivation, Learning Outcomes. 


\section{PENDAHULUAN}

$\mathrm{P}$ endidikan adalah usaha sadar dan terencana untuk mewujudkan suasana belajar dan proses pembelajaran agar peserta didik secara aktif mengembangkan potensi dirinya untuk memiliki kekuatan spiritual keagamaan, pengendalian diri, kepribadian, kecerdasan, akhlak mulia, serta keterampilan yang diperlukan dirinya, masyarakat, bangsa dan negara (Undang-Undang Sistem Pendidikan no. 20 tahun 2003). Tujuan dari diselenggarakannya pendidikan adalah peserta didik secara aktif dapat mengembangkan potensi yang ada di dalam dirinya sehingga menjadi manusia berkualitas. Menciptakan sumber daya manusia berkualitas merupakan cita-cita seluruh bangsa dan negara di dunia. Sumber daya manusia berkualitas adalah produk lembaga pendidikan berkualitas.

Pendidikan dikatakan berkualitas apabila dalam pendidikan itu terlaksana kegiatan pembelajaran yang terencana, terprogram serta menggunakan model pembelajaran yang inovatif, variatif, dan evaluasi yang tepat serta menggunakan media yang relevan dengan perkembangan ilmu dan teknologi. Hal ini seperti yang tertuang pada Standar Isi dalam Lampiran Peraturan Menteri Pendidikan Nasional Nomor 22 Tahun 2006 yang menyatakan bahwa pendidikan nasional berfungsi mengembangkan kemampuan dan mem-bentuk watak serta peradaban bangsa yang bermartabat dalam rangka mencerdaskan kehidupan bangsa, bertujuan untuk mengembangkan potensi peserta didik agar menjadi manusia yang beriman dan bertakwa kepada Tuhan Yang Maha Esa, berakhlak mulia, sehat, berilmu, cakap, kreatif, mandiri, dan menjadi warga negara yang demokratis serta bertanggung jawab.

IPA berhubungan dengan cara mencari tahu tentang alam secara sistematis, sehingga IPA bukan hanya penguasaan kumpulan pengetahuan yang berupa fakta-fakta, konsep-konsep atau prinsip-prinsip saja, tetapi juga merupakan suatu proses penemuan (Sulistyorini, 2007). IImu Pengetahuan Alam merupakan mata pelajaran di SD yang dimaksudkan agar siswa mempunyai pengetahuan, gagasan dan konsep yang terorganisasi tentang alam sekitar, yang diperoleh dari pengalaman melalui serangkaian proses ilmiah antara lain penyelidikan, penyusunan dan penyajian gagasan-gagasan. Pada prinsipnya, mem-pelajari IPA sebagai cara mencari tahu dan cara mengerjakan atau melakukan dan membantu siswa untuk memahami alam sekitar secara lebih mendalam (Depdiknas dalam Suyitno, 2002). Tujuan utama pembelajaran IPA adalah agar peserta didik memahami konsep-konsep IPA secara sederhana dan mampu meng-gunakan metode ilmiah untuk memecahkan masalah-masalah yang dihadapi dengan lebih menyadari kebesaran dan kekuasaan pencipta alam. Agar tujuan tersebut tercapai, maka IPA perlu diajarkan dengan cara yang tepat dengan melibatkan peserta didik secara aktif dalam pembelajaran. IImu Pengetahuan Alam (IPA) di Sekolah Dasar menuntut peserta didik untuk mempunyai wawasan, keterampilan, dan sikap ilmiah sejak dini. Pembelajaran IPA dikatakan berhasil apabila semua tujuan pembelajaran yang telah ditentukan dapat tercapai, yang terungkap dalam hasil belajar IPA. Namun dalam kenyataannya, masih ada sekolah-sekolah yang memiliki hasil belajar IPA yang rendah karena belum mencapai standar ketuntasan yang telah ditentukan.

Berdasarkan hasil observasi awal di SD Negeri Brubuh 2, hasil belajar IPA masih rendah. Pada saat kondisi awal, rata-rata nilai ulangan harian IPA siswa kelas IV yaitu 60,38\%, padahal batas kriteria ketuntasan minimal (KKM) adalah 70. Berdasarkan kenyataan tersebut, dari 21 siswa kelas IV yang mampu mencapai nilai di atas KKM hanya 8 siswa $(38,1 \%)$, sedangkan sisanya 13 siswa memperoleh nilai di bawah KKM tersebut. Hal ini dikarenakan hampir 61,9\% siswa kurang memahami dan menguasai materi pembelajaran. Dari hasil wawancara guru dan siswa kelas IV SD Negeri Brubuh 2 tersebut 
diketahui bahwa rendahnya hasil belajar IPA disebabkan karena beberapa faktor yang mempengaruhi selama proses pembelajaran berlangsung.

Faktor-faktor yang mempengaruhi proses pembelajaran IPA diantaranya adalah metode pembelajaran yang digu-nakan guru masih bersifat konven-sional (teacher centered), antusias siswa dalam belajar IPA rendah, dan belum ada penggunaan media pembelajaran. Selama proses pembelajaran IPA berlangsung, sumber belajar yang digunakan adalah buku paket dan LKS saja. Belum ada media pembelajaran yang digunakan ketika pembelajaran berlangsung. Se-hingga kegiatan siswa hanya menulis, membaca, dan mendengarkan ceramah dari guru. Akibatnya, siswa menjadi kurang tertarik terhadap pembelajaran dan motivasi belajar siswa rendah.

Permasalahan-permasalahan di atas harus segera diatasi dan dicarikan solusi yang tepat. Guru harus melakukan inovasi-inovasi dalam pembelajaran. Salah satu inovasi tersebut adalah dengan menggunakan media pembelajaran. Dalam hal ini Dick \& Carey (dalam Lamudji, 2005) menyatakan bahwa salah satu keputusan yang paling penting dalam merancang pembelajaran ialah dengan menggunakan media yang sesuai dalam rangka penyampaian pesan-pesan pembe-lajaran. Penggunaan media pembelajaran pada tahap orientasi pembelajaran akan sangat membantu keefektifan proses pembelajaran dan penyampaian informasi pesan dan isi pelajaran pada saat itu. Hal ini sejalan dengan pendapat menurut Indriana (2011) bahwa media berfungsi mengarahkan siswa untuk memperoleh berbagai pengalaman belajar (learning experience). Pengalaman belajar tergan-tung pada interaksi siswa dengan media, dan media yang tepat dan sesuai dengan tujuan belajar akan mampu meningkatkan pengalaman belajar sehingga anak didik bisa mempertinggi hasil belajar.

Media pembelajaran bermanfaat untuk melengkapi, memelihara dan bahkan meningkatkan kualitas dan proses pembe-lajaran yang sedang berlangsung, penggunaan media dalam pembelajaran akan meningkatkan hasil belajar, meningkatkan aktivitas siswa, meningkatkan motivasi belajar siswa. Selain membangkitkan motivasi dan minat siswa, media pembelajaran juga dapat membantu siswa meningkatkan pemahaman, menyajikan data dengan menarik dan terpercaya, memudahkan penafsiran data, dan memadatkan informasi (Arsyad, 2013). Jadi, dengan hadirnya media pembelajaran tersebut dapat menghasilkan proses pembelajaran menyenangkan, kreatif, inovatif dan tidak membosankan yang akan menjadi pilihan tepat bagi para pendidik.

Dalam hal ini, guru dapat memilih salah satu alternatif yang digunakan dalam pembelajaran yaitu pemanfaatan teknologi multimedia yang sering disebut media pembelajaran multimedia interaktif. Alasan pemilihan media ini karena multimedia interaktif dapat merangsang siswa agar lebih aktif dalam memahami suatu pembelajaran dengan gambar-gambar, suara dan video yang atraktif dan menarik sehingga perhatian siswa dapat terfokus dalam pembelajaran. Alasan pemilihan tersebut sejalan dengan hasil penelitian tentang pembelajaran menggunakan multimedia interaktif yang dilakukan oleh Somatkar (2012), yaitu media pembelajaran yang interaktif tidak hanya berkontribusi pada guru tetapi berpusat pada siswa yang mendukung pembelajarannya, dan me-mungkinkan pemahaman, berkonsentrasi, merangsang belajar serta meningkatkan motivasi, kepercayaan diri, perhatian dan minat siswa. Pemilihan media ini dapat membantu siswa melaksanakan pembelajaran mandiri, dengan menu-menu yang didesain sedemikian rupa sehingga memberi kebebasan kepada siswa untuk memilih materi yang hendak dipelajari khususnya dalam pelajaran IPA materi struktur organ tubuh manusia dan fungsinya. Multimedia interaktif ini dapat menjadi media pembelajaran yang melibatkan keseluruhan sisi kognitif, afektif dan psikomotor anak. 
Tujuan dari penelitian ini adalah: 1) Meningkatkan motivasi belajar siswa melalui penerapan multimedia interaktif dalam pembelajaran IPA kelas IV SD Negeri Brubuh. 2) Meningkatkan hasil belajar siswa melalui penerapan multimedia interaktif dalam pembelajaran IPA kelas IV SD Negeri Brubuh 2.

\section{METODE PENELITIAN}

Penelitian ini merupakan penelitian tindakan kelas (classroom action research). Penelitian dilakukan dengan merancang, melaksanakan, merefleksikan tindakan secara kolaboratif dan partisipasi bertujuan untuk memperbaiki proses pembelajaran di kelas melalui suatu tindakan dalam suatu siklus.

Subjek dalam penelitian ini adalah siswa kelas IV semester I tahun ajaran 2015/2016, dengan jumlah subjek sebanyak 21 peserta didik. Adapun yang dijadikan sebagai objek adalah motivasi belajar dan hasil belajar peserta didik pada pelajaran IPA materi struktur organ tubuh manusia dan fungsinya.

Prosedur penelitian ini dilaksanakan dalam bentuk siklus berulang-ulang, setiap siklus terdapat empat tahapan, yaitu: perencanaan (planning), pelaksanaan (acting), pengamatan (observing), dan refleksi (reflecting) (Iskandar, 2011).

Metode pengumpulan data yang digunakan berupa tes dan non-tes. Metode tes digunakan untuk memperoleh data mengenai hasil belajar. Instrumen pada metode ini berupa tes hasil belajar tiap-tiap siklus, baik pre-test dan post-test. Pre-test digunakan untuk mengetahui penguasaan awal terhadap materi kom-petensi membaca cermat, sedangkan post-test digunakan untuk mengukur tingkat keberhasilan setelah diberikan tindakan. Metode non-tes berupa kuisioner/angket, observasi, dan wawancara mendalam. Angket digunakan untuk mengetahui motivasi siswa terhadap pembelajaran IPA sebelum dan sesudah mengikuti pembe-lajaran dengan penerapan multimedia interaktif. Observasi dilakukan oleh peneliti dengan melakukan penilaian terhadap aktivitas siswa terhadap pembe-lajaran dan kinerja guru kelas. Wawancara dilakukan kepada peserta didik yang menonjol. Hasil wawancara ini digunakan untuk memperkuat data yang telah diperoleh melalui metode pengumpulan data lainnya.

Teknik analisis data yang diguna-kan dalam penelitian ini adalah model analisis interaktif (Miles dan Huberman dalam Kunandar, 2010). Menurut Iskandar (2011) dalam proses analisis data interaktif terdapat tiga langkah yang harus dilakukan oleh peneliti, yaitu: (1) reduksi data, (2) display atau penyajian data, dan (3) mengambil kesimpulan atau verifikasi.

Teknik yang digunakan untuk memeriksa validitas data adalah tri-angulasi. Penelitian ini menggunakan teknik triangulasi data dan triangulasi metode. Adapun yang dimaksud kedua hal tersebut adalah: a) Triangulasi Sumber Data. Pada penelitian ini, peneliti memperoleh data dari beberapa sumber, yaitu: guru kelas IV SD Negeri Brubuh 2 dan siswa kelas IV, hasil observasi pembelajaran IPA dengan penerapan multimedia interaktif, data nilai pra siklus, data post-test dan pre-test pada masingmasing siklus. b) Triangulasi metode. Pada penelitian ini peneliti menggunakan metode penelitian berupa observasi terhadap kinerja guru dan aktivitas siswa kelas IV SD Negeri Brubuh 2.

\section{HASIL PENELITIAN}

Berdasarkan hasil refleksi siklus II dan rata-rata nilai siswa pada siklus II, maka dapat disimpulkan bahwa pembe-lajaran IPA materi struktur organ tubuh manusia dan fungsinya pada siklus II berhasil mencapai target indikator kinerja, yaitu motivasi dan hasil belajar siswa mencapai lebih dari $80 \%$. Hasil penelitian yang telah dilakukan menunjukkan bahwa terjadi peningkatan hasil belajar siswa, diantaranya 
peningkatan rata-rata kelas dari kondisi awal 60,38 menjadi 72,14 pada siklus I dan menjadi 83,09 pada siklus II. Nilai terendah meningkat dari kondisi awal 50 menjadi 60 pada siklus I dan 65 pada siklus II. Nilai tertinggi meningkat dari kondisi awal 76 menjadi 90 pada siklus I dan 100 pada siklus II. Selain itu persentase ketuntasan belajar klasikal atau jumlah siswa yang mencapai KKM $\geq 70$ juga mengalami peningkatan dari kondisi awal 38,1\% menjadi $66,7 \%$ pada siklus I dan $90,47 \%$ di siklus II. Persentase motivasi siswa terhadap pembelajaran IPA dengan memanfaatkan penerapan multimedia interaktif juga mengalami peningkatan dari $67,43 \%$ pada siklus I dan $84,23 \%$ di siklus II. Dengan demikian peneliti tidak perlu melanjutkan penelitian pada siklus berikutnya, dan dapat disimpulkan bahwa penerapan multimedia interaktif dapat meningkatkan motivasi dan hasil belajar IPA siswa kelas IV SD Negeri Brubuh 2. Rangkuman hasil penelitian ini dapat dilihat pada tabel dan histogram sebagai berikut:

Tabel 1. Rekapitulasi Hasil Tindakan

\begin{tabular}{cccc}
\hline Kriteria & Pra Siklus & Siklus I & Siklus II \\
\hline Rata-rata & 60,38 & 72,14 & 83,09 \\
\hline Nilai Terendah & 50 & 60 & 65 \\
\hline Nilai Tertinggi & 76 & 90 & 100 \\
\hline Ketuntasan Belajar & $38,1 \%$ & $66,7 \%$ & $90,47 \%$ \\
\hline Motivasi Siswa & $0 \%$ & $67,43 \%$ & $84,23 \%$ \\
\hline
\end{tabular}
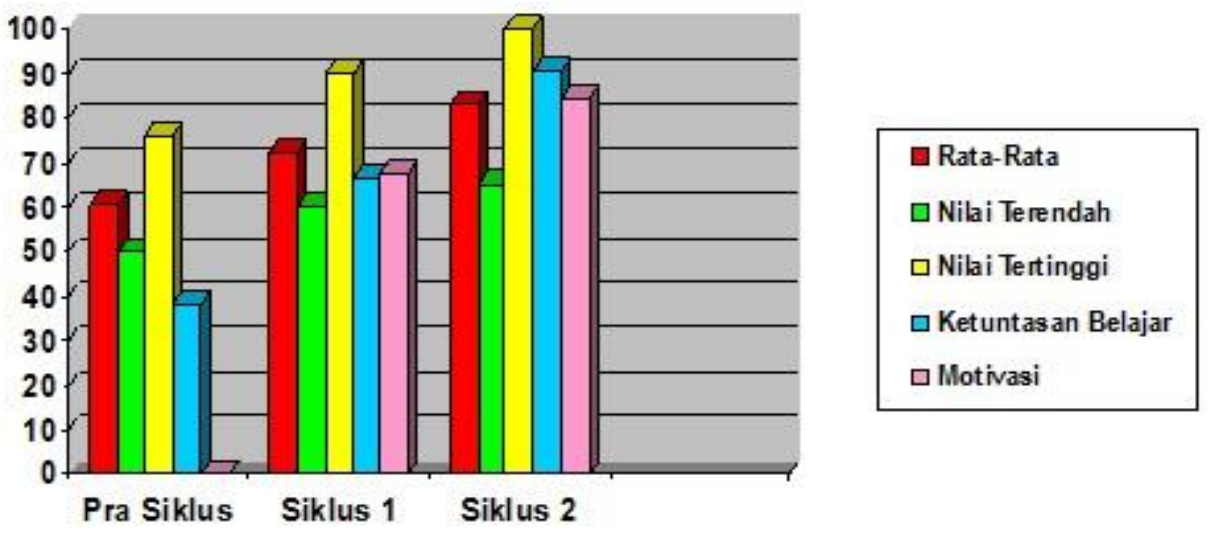

Gambar 1. Pra Siklus, Siklus 1, dan Siklus 2

\section{PEMBAHASAN}

Hasil analisis data penelitian menun-jukkan bahwa media pembelajaran berpengaruh terhadap motivasi dan hasil belajar siswa. Secara lebih spesifik, hasil belajar IPA yang menerapkan media pembelajaran multimedia interaktif lebih baik daripada hasil belajar IPA yang masih menerapkan pembelajaran konvensional (berpusat pada guru). Hal tersebut karena hasil belajar adalah hasil dari suatu inter-aksi tindak belajar mengajar (Nasution, 2006). Hasil interaksi tindak belajar mengajar dapat berupa penggunaan media pembelajaran, pemilihan metode pembe-lajaran, dan lain sebagainya. Hal tersebut sesuai dengan pendapat Baharuddin dan Wahyuni $(2008,19)$ bahwa terdapat faktor-faktor eksternal lingkungan non-sosial yang mempengaruhi hasil belajar, yaitu lingkungan alamiah, faktor instru-mental, faktor materi pelajaran yang diajarkan ke siswa. 
Penerapan multimedia interaktif untuk pembelajaran struktur organ tubuh manusia dan fungsinya sudah tepat dan sesuai dengan tujuan belajar yang nantinya akan mampu meningkatkanpengalaman belajar sehingga anak didik bisa memper-tinggi hasil belajar, hal ini sesuai dengan pendapat dari Indriana (2011). Dengan digunakannya media pembelajaran multi-media interaktif telah mampu memberikan hasil belajar IPA yang sangat memuaskan. Multimedia interaktif pada pembelajaran IPA Kelas IV SD yang diterapkan peneliti merupakan salah satu multimedia pembel-ajaran yang cukup sederhana dalam pengoperasiannya, tetapi cukup mudah dipahami dan cukup lengkap informasi yang disajikan, sehingga merupakan salah satu alternatif yang dapat digunakan oleh sekolah untuk mengadakan proses perbaikan terhadap pembelajaran IPA Kelas IV SD Negeri Brubuh 2. Multimedia interaktif ini sesuai dengan definisi multimedia yang dikemukakan oleh Munir (2012) bahwa multimedia merupakan perantara atau sesuatu yang dipakai untuk menghantarkan, menyampaikan atau mem-bawa sesuatu. Hal yang disampaikan dalam multimedia interaktif ini adalah materi pelajaran IPA untuk siswa kelas IV.

Multimedia interaktif yang diterap-kan mampu menarik minat dan motivasi siswa untuk belajar, dan materi yang ada di dalamnya membuat siswa menjadi mudah untuk memahami materi tersebut. Hal ini sesuai dengan pengertian multi-media yang diungkapkan oleh Arsyad (2002) bahwa multimedia bertujuan untuk menyajikan informasi dalam bentuk yang menyenangkan, menarik, mudah dime-ngerti, dan jelas. Selain itu multimedia ini dilengkapi dengan teks, audio, gambar, animasi, interaktivitas dan berbasis TIK. Hal ini sesuai dengan definisi multimedia menurut Constantinesceu (2007) bahwa multimedia merujuk kepada sistem ber-basis komputer yang menggunakan ber-bagai jenis isi seperti teks, audio, video, grafik, animasi dan interaktifitas.

Hasil yang sama juga telah ditunjukkan oleh Salter et al. (2012) bahwa sebuah media pembelajaran inter-aktif yang dibuat secara kreatif yang dirancang untuk mempengaruhi dan me-motivasi siswa secara bersamaan mening-katkan hasil belajar, dan merupakan sarana yang valid dan berharga dalam portofolio pembelajaran dan sumber belajar, terutama untuk masa awal tahun pertama di suatu sekolah. Hasil dari penelitian ini, sesuai dengan hasil penelitian dari Hakim (2014) yang berjudul, "Pengaruh Penggunaan Multimedia Inter-aktif Dan Video Terhadap Prestasi Belajar Ipa Kelas V Ditinjau Dari Motivasi Belajar", yaitu peserta didik yang mema-kai multimedia pembelajaran mengalami peningkatan prestasi belajar dari pada siswa yang tidak memakai multimedia. Kemudian, hasil penelitian ini juga sesuai dengan hasil penelitian yang dilakukan oleh Vonny (2015) yang berjudul, "Pengaruh Media Pembelajaran Multimedia Interaktif Terhadap Hasil Belajar Hakikat Geografi Ditinjau Dari Motivasi Belajar". Hasil penelitian menunjukkan bahwa motivasi peserta didik yang menggunakan multimedia interaktif lebih tinggi daripada peserta didik yang tidak menggunakan multimedia yang mengaki-batkan hasil belajar Geografi meningkat.

Dari kedua penelitian tersebut, hasil yang diperoleh sesuai dengan hasil dari penelitian ini, yaitu setelah dilakukan penelitian tindakan kelas dengan penerapan multimedia interaktif dalam pembelajaran IPA materi struktur organ tubuh manusia dan fungsinya maka pemahaman/hasil belajar peserta didik meningkat, dan motivasi belajar peserta didik terhadap pembelajaran IPA pun meningkat.

\section{KESIMPULAN}

Hasil penelitian menunjukkan bahwa terjadi peningkatan motivasi belajar siswa. Persentase motivasi siswa terhadap pembelajaran IPA dengan memanfaatkan penerapan multimedia interaktif adalah sebesar $67,43 \%$ pada siklus I dan meningkat menjadi $84,23 \%$ pada siklus II. Hasil penelitian 
menunjukkan bahwa terjadi peningkatan hasil belajar siswa, diantaranya peningkatan rata-rata kelas dari kondisi awal 60,38 menjadi 72,41 pada siklus I dan 83,09 pada siklus II. Nilai terendah meningkat dari kondisi awal 50 menjadi 60 pada siklus I dan 65 pada siklus II. Nilai tertinggi meningkat dari kondisi awal 76 menjadi 90 pada siklus I dan 100 pada siklus II. Jumlah siswa yang mencapai KKM $\geq 70$ juga mengalami peningkatan dari kondisi awal 38,1\% menjadi 66,7\% pada siklus I dan 90,47\% di siklus II. Kedua variabel penelitian tindakan kelas ini telah memenuhi syarat kriteria keberhasilan penelitian, yaitu motivasi dan ketuntasan hasil belajar siswa mencapai $80 \%$.

Motivasi dan hasil belajar siswa pada pembelajaran IPA materi struktur organ tubuh manusia dan fungsinya meningkat dikarenakan adanya perbaikan proses pembelajaran yang dilakukan oleh guru dan peneliti selama dua siklus dalam 4 kali tindakan dan 4 kali pertemuan. Selain itu multimedia interaktif dapat mempermudah siswa dalam belajar untuk memperoleh informasi edukatif yang autentik dimana saja dan kapan saja serta sesuai dengan tujuan pembelajaran. Siswa didorong untuk menyelami informasi tersebut secara mandiri dalam memahami dan menarik kesimpulan pembelajaran. Pada multimedia interaktif juga telah disediakan konten materi, kuis, dan permainan yang edukatif, animatif, dan menarik sehingga dapat mempermudah pemahaman materi siswa dan meningkatkan motivasi siswa terhadap pembelajaran tersebut yang berdampak pada peningkatan hasil belajar yang telah diharapkan sebelumnya, yaitu $80 \%$ siswa tuntas mencapai nilai $\mathrm{KKM} \geq 70$.

\section{IMPLIKASI}

Berdasarkan kesimpulan diatas diketahui bahwa motivasi dan hasil belajar siswa meningkat setelah dilakukan penerapan multimedia interaktif pada pembelajaran IPA, maka penelitian ini dapat digunakan sebagai acuan dalam upaya meningkatkan motivasi dan hasil belajar siswa. Secara tidak langsung, hal ini juga berimplikasi pada guru dalam melaksanakan pembelajaran. Dalam ke-giatan pembelajaran guru dituntut untuk mampu memilih media pembelajaran yang tepat, dan sesuai dengan tujuan yang akan dicapai. Pemilihan media pembelajaran yang tepat dengan memanfaatkan sumber daya secara maksimal dan melibatkan peserta didik secara aktif dalam kegiatan pembelajaran, akan mampu mendukung pencapaian tujuan pembelajaran secara optimal. Dalam penelitian ini telah terbukti bahwa dengan penerapan multimedia interaktif dalam pembelajaran IPA dapat berpengaruh terhadap peningkatan motivasi dan hasil belajar siswa.

\section{SARAN}

Bagi Siswa SD Negeri Brubuh 2. Sebagai seorang siswa harus selalu menghormati dan menghargai guru. Siswa harus mampu mempertahankan keaktifan dalam kegiatan pembelajaran, yaitu dengan berani menyampaikan pendapat, berani bertanya kepada guru terhadap materi pembelajaran yang belum dipahami, dan berani menanggapi jawaban dari teman yang kurang tepat. Selain itu, siswa harus meningkatkan perhatian ketika guru menyampaikan materi pembelajaran, meningkatkan kerjasama dalam diskusi kelompok, meningkatkan ketekunan dan tanggung jawab selama pembelajaran berlangsung. Bagi Guru di SD Negeri Brubuh 2. Dari hasil penelitian ini, peneliti merekomendasikan multimedia interaktif kepada guru kelas dan guru lainnya sebagai salah satu solusi atau sarana untuk meningkatkan motivasi dan hasil belajar siswa. Guru dapat memotivasi siswa untuk meningkatkan hasil belajarnya dengan berupaya melakukan variasi-variasi penggunaan media pembelajaran atau model pembelajaran. Ketepatan pemilihan media pembelajaran sangat menentukan tercapainya tujuan 
pembelajaran. Seperti pada penelitian ini yang memilih multimedia interaktif sebagai media pembelajaran, dan terbukti mampu meningkatkan motivasi dan hasil belajar siswa.

Bagi Sekolah. Berdasarkan keber-hasilan penelitian ini, maka pihak sekolah melalui Kepala Sekolah dapat menya-rankan penerapan media pembelajaran yang tepat, dan memotivasi guru kelas untuk melakukan inovasi media pembe-lajaran untuk meningkatkan kualitas, mutu, dan hasil pembelajaran. 


\section{DAFTAR PUSTAKA}

Suyitno, A. (2002). Prosedur Penelitian Tindakan Kelas. Bogor: Ghalia Indonesia.

Anitah, S. (2009). Strategi Pembelajaran di SD. Jakarta: Universitas Terbuka.

Arsyad, A. (2013). Media Pembelajaran. Jakarta: PT. Raja Grafindo Persada.

Badan Standar Nasional Pendidikan. (2006). Standar Isi Untuk Satuan Pendidikan Dasar dan Menengah. Jakarta: Depdiknas.

Badan Standar Nasional Pendidikan. (2006) .Standar Kompetensi dan Kompetensi Dasar. Jakarta : BNSP

Indriana. (2011). Ragam Alat Bantu Media Pengajaran. Jogjakarta: Diva Pers.

Iskandar. (2011). Penelitian Tindakan Kelas. Jakarta: Gaung Persada.

Kunandar, (2010). Penelitian Tindakan Kelas. Jakarta: Rajawali Pers

Hakim, P. R. (2014). Pengaruh Penggunaan Multimedia Interaktif Dan Video Terhadap Prestasi Belajar Ipa Kelas V Ditinjau Dari Motivasi Belajar. Tesis. Surakarta: PPs UNS

Somatkar, B. W. (2012). Aims and Objectives of Teaching English in India. India: Indian Streams Research Journal

Arikunto, S. (2010). Penelitian Tindakan: Untuk Guru, Kepala Sekolah, \& Pengawas. Yogyakarta: Aditya Media.

Sulistyorini, S. (2007). Model Pembelajaran IPA Sekolah Dasar dan Penerapannya dalam KSTP. Yogyakarta: Tiara Wacana.

Vonny. (2015). Pengaruh Media Pembelajaran Multimedia Interaktif Terhadap Hasil Belajar Hakikat Geografi Ditinjau Dari Tingkat Motivasi Belajar Geografi. Tesis. Surakarta: PPs UNS. 